\title{
Coag-Flocculation Kinetics and Functional Parameters Response of Mucuna Seed Coagulant to pH Variation in Organic Rich Coal Effluent Medium
}

\author{
M.C. Menkiti ${ }^{1 *}$, P.C. Nnaji ${ }^{2}$, C.I. Nwoye ${ }^{3}$, O.D. Onukwuli ${ }^{1}$
}

\author{
${ }^{1}$ Department of Chemical Engineering, Nnamdi Azikiwe University, Awka, Nigeria. \\ ${ }^{2}$ Enugu State Water Corporation, Enugu, Nigeria \\ ${ }^{3}$ Department of Metallurgical and Materials Engineering, Federal university of Technology \\ Owerri, Nigeria
}

*Corresponding author: cmenkiti@yahoo.com

\begin{abstract}
The coag-flocculation performance of Mucuna Seed Coagulant as affected by $p H$ variation in coal washery effluent has been investigated at room temperature using various dosages of unblended Mucuna Seed Coagulant. In addition, coag-flocculation parameters such as Coagflocculation reaction order $\alpha, \alpha^{\text {th }}$ order coag-flocculation constant $K$, Collision factor for Brownian Transport $\beta_{B r}$, Smoluchowski constant $K_{R}$, Collision Efficiency $\varepsilon_{p}$, and Coagulation Period $\tau_{1 / 2}$ were determined. Turbidity measurement was employed using the nephelometric (turbidimetric) standard method while Mucuna Seed Coagulant preparation was adopted from the works of Adebowale and Adebowale (2007). The maximum Mucuna Seed Coagulant parameter performance is recorded at $\alpha$ of 2, K of $8.3334 \times 10^{-3} \mathrm{~m}^{3} / \mathrm{kg} . s$, dosages of $\left(0.15 \mathrm{~kg} / \mathrm{m}^{3}\right.$; $\left.0.2 \mathrm{~kg} / \mathrm{m}^{3} ; 0.25 \mathrm{~kg} / \mathrm{m}^{3}\right) ; p H$ of 6 and $\tau_{1 / 2}$ of $1.7339 \mathrm{sec}$ while the minimum parametric performance is recorded at $\alpha$ of $1 ; K$ of $6.3001 \times 10^{-4} \mathrm{~s}^{-1}$; dosage of $0.2 \mathrm{~kg} / \mathrm{m}^{3} ; \mathrm{pH}$ of 8 and $\tau_{1 / 2}$ of 1100.2161 seconds. The minimum value of coag-flocculation efficiency $E(\%)$ recorded is greater than $88.00 \%$. Conclusively; Mucuna Seed Coagulant is an effective coagulant obeying the theory of fast coagulation at the conditions of the experiment.
\end{abstract}

Keywords: Coag-flocculation, Kinetics, Coal effluent, Mucuna, Coagulation

\section{INTRODUCTION}

\subsection{Background}

Coag-flocculation is a core purification process, which finds wide range of application in water and waste water treatment facilities. Conceptually, Coag-flocculation is the process of adding substances to aqueous effluent to make suspended particles to bind together (coagulate) and subsequently aggregating into visible flocs (flocculation) that settle out of the water. This is achieved when the stabilized particles are aided to overcome their repulsive forces to form blobs of flocs $[1,2,3,4]$. Among the factors that affect the process are raw effluent quality, temperature, $\mathrm{pH}$, etc [5].

In particular, coag-flocculation in conjunction with other treatment processes is regarded as a viable option for the treatment of aqueous effluent such as coal washery effluent. Coagflocculation can be achieved by any of the common coagulants such as alum, lime etc. The 
Coag-flocculation behaviors of these common compounds have been well investigated with little or no attention given to the Coag-flocculation potentials of bio derivatives. To this end, a focus is hereby given to the study on Mucuna bean seed (MBS) as a potential source of Coagflocculation derivative. Mucuna sloanei is an annual twinning tropical plant with pods containing seed bean, which is the bearer of the active components (proteins) that is processed into Mucuna Seed Coagulant (MSC). The seeds are high in proteins (20-30\%), lipids, fibers, minerals and Ldopa [6]. MSC is a non-toxic, biodegradable and biocompatible compound.

Against this backdrop, this work endeavors to explore and generate interest in the utilization of MBS as a coagulant. Also investigated are Coag-flocculation performance and kinetics of MSC under various $\mathrm{pH}$ of coal washery effluent, a typical medium for this kind of study. Thus, if well developed, MSC takes on a significant importance towards finding alternative replacement for the chemical coagulants/flocculants.

\subsection{Theoretical Principles and Model Development}

For a uniformly composed coag-flocculation phase with negligible influence of external forces:

$$
\begin{aligned}
& \mu_{i}=\bar{G}_{i}=\left[\frac{\partial G}{\partial n_{i}}\right]_{P, T, n}=\text { a constant } \\
& \text { Thus } d \mu_{i}=0 \\
& \text { For each of the species } i \text { present [7]. } \\
& G \text { is the total Gibbs free energy } \\
& n_{i} \text { is the number of moles of component } i
\end{aligned}
$$

For dilute solutions

$$
\mu_{i} \approx \mu_{i}^{o}+R T \ln C_{i}
$$

A shift from the equilibrium generates diffusional process represented by:

$$
f_{d}=-\frac{d \mu}{d x}
$$

Recall $K_{B}=R / N$ such that for single $N, K_{B}=R$

Hence $\mu_{i} \approx \mu_{i}^{o}+K_{B} T \ln C_{i}$

Where $K_{B}$ is Boltzmann constant; $\mu_{i}$ is chemical potential

$R$ is universal gas constant; $\mathrm{Ci}$ is concentration

$N$ is Avogadro's constant; $x$ is diffusion distance

Combining equations 4 and 5 yield:

$$
\begin{aligned}
f_{d} & =-\frac{d}{d x}\left(\mu_{i}^{0}+K_{B} T \ln C_{i}\right) \\
f_{d} & =-\frac{K_{B}}{C_{i}} \frac{d C_{i}}{d x}
\end{aligned}
$$

The viscous drag force on the particles due to surrounding fluid is:

$$
\begin{aligned}
& \quad f_{d}=B U_{d} \\
& \text { And } \quad J_{i}=C U_{d} \\
& \text { Where } B \text { is friction factor } \\
& U_{d} \text { is terminal diffusing velocity } \\
& J_{i} \text { is flux of diffusing material } \\
& f_{d} \text { is drag force }
\end{aligned}
$$

From Fick's law

$$
D^{\prime}=-J /(d c / d x)
$$

Where $D^{\prime}$ is diffusion coefficient 
Combining equations 8,9 and 10 yield

$$
D^{\prime}=\frac{-f_{d}}{B} \frac{c}{(d c / d x)}
$$

Comparing equations 7 and 11 generate Einstein's equation:

$$
D^{\prime}=\frac{K_{B} T}{B}
$$

For similar phase, the rate of successful collisions between particles of sizes $i$ and $j$ to form particle of size $K$ is $[8,5]$ :

$\mathrm{N}_{\mathrm{ij}}=\varepsilon_{\mathrm{p}} \beta(\mathrm{i}, \mathrm{j}) \mathrm{n}_{\mathrm{i}} \mathrm{n}_{\mathrm{j}}$

where $\mathrm{N}_{\mathrm{ij}}$ is the rate of collisions between particles of size $\mathrm{i}$ and $\mathrm{j}$ (mass concentration / time)

$\varepsilon_{\mathrm{p}}$ is collision efficiency

$\beta(\mathrm{i}, \mathrm{j})$ is collision factor between particles of size $i$ and $j$

$n_{i} n_{j}$ is particle concentration for particles of size $i$ and $j$, respectively.

Assuming monodisperse, no break up and bi particle collision, the general model for perikinetic coag-flocculation is given as $[9,5]$

$\frac{d n_{k}}{d t}=\frac{1}{2} \sum_{i+j=k} \beta(i, j) n_{i} n_{j}-\sum_{i=1}^{\infty} \beta(i, k) n_{i} n_{k}$

where $\frac{d n_{k}}{d t}$ is the rate of change of concentration of particle of size $K$ (concentration / time).

$\beta$ is a function of the coag-flocculation transport mechanism. The appropriate value of $\beta$ for Brownian transport is given by [10]:

$\beta_{B R}=\frac{8}{3} \varepsilon_{p} \frac{k_{B} T}{\eta}$

Where $k_{B}$ is Boltzmann's constant $(\mathrm{J} / \mathrm{K})$

$T$ is Absolute temperature (K)

The generic aggregation rate of particles (during coagulation / flocculation) can be derived by the combination of equations 2 and 3 to yield:

$-\frac{d N_{t}}{d t}=K N_{t}^{\alpha}$

Where $N_{t}$ is total particle concentration at time $t, N_{t}=\sum n_{k}$ (mass / volume)

$K$ is the $\alpha^{\text {th }}$ order coag-floculation constant

$\alpha$ is the order of coag-floculation process

And $K=\frac{1}{2} \beta_{B R}$

Where $\beta_{B R}$ is collision factor for Brownian transport

Also, $\beta_{B R}=\varepsilon_{p} K_{R}$

Combining equations 4,5 and 6 produce:

$-\frac{d N_{t}}{d t}=\frac{1}{2} \beta_{B R} N_{t}^{\alpha}$

$$
=\frac{1}{2} \varepsilon_{p} \cdot K_{R} N_{t}^{\alpha}
$$

Where $K_{R}$ is the Von smoluchowski rate constant for rapid coagulation [10]

However $K_{R}=8 \pi R D^{\prime}$

$$
R_{p}=2 a
$$

Where $\quad D^{\prime}$ is particle diffusion coefficient

$a$ is particle radius.

From Einstein's equation: $D_{1}=K_{B} T / B$ 
From Stroke's equation: $B=6 \pi \eta a$

where $B$ is the friction factor

$\eta$ is the viscosity of the fluid

combining equations 21 to 24 gives:

$$
-\frac{d N_{t}}{d t}=\frac{4}{3} \varepsilon_{p} \frac{K_{B} T}{\eta} N_{t}^{\alpha}
$$

Comparing equations 16 and 25 show:

$$
K=\frac{4}{3} \varepsilon_{p} \frac{K_{B} T}{\eta}
$$

For perikinetic aggregation, $\alpha$ theoretically equals 2 as would shown below $[12,7]$ :

From Fick's law,

$$
J_{f}=D^{\prime} 4 \pi R_{p}^{2} \frac{d N_{t}}{d R}
$$

Integrating equation 27 at initial conditions $N_{t}=0, R=2 a$ :

$$
\frac{J_{f}}{D^{\prime} 4 \pi} \int_{0}^{R_{p}} \frac{d R_{p}}{R_{p}{ }^{2}}=\int_{N_{0}}^{N_{t}} d N_{t}
$$

Therefore $J_{f}=8 \pi D^{\prime} a N_{0}$

$$
=\frac{1}{2} \cdot K_{R} \cdot N_{0}
$$

For central particle of same size undergoing Brownian motion, the initial rate of rapid coagflocculation is:

$$
\begin{gathered}
-\frac{d N_{t}}{d t}=J_{f} \cdot \varepsilon_{p} \cdot N_{0} \\
=\frac{1}{2} \cdot K_{R} \cdot \varepsilon_{p} \cdot N_{0}^{2} \\
=\frac{4}{3} \varepsilon_{p} \frac{K_{B} T}{\eta} \cdot N_{0}^{2} \\
\equiv \frac{4}{3} \varepsilon_{p} \frac{K_{B} T}{\eta} N_{t}^{2} \text { at } t>0
\end{gathered}
$$

Hence, from equation $32, \alpha=2$

However in real practice, empirical evidence shows that in general $1 \leq \alpha \leq 2[13,14]$. Based on this , what is required to evaluate $K$ is to determine the line of better fit between $\alpha=1$ and 2 while the experimental data are fitted into linearised form of equation 16.

Hence, for $\alpha=1$, equivalence of equation 16 yields:

$$
\frac{d N}{d t}=-K N
$$

Integrating within the limits produces

$$
\begin{array}{cc}
\int_{N_{0}}^{N} \frac{d N}{N}=-\int_{0}^{t} K d t \\
\text { Hence } \quad \ln (1 / N)=K t-\ln N_{0}
\end{array}
$$

Plot of $\ln (1 / N)$ vs.t gives a slope of $K$ and intercept of $\left(-\ln N_{0}\right)$.

For $\alpha=2$; equivalence of equation 16 yields:

$$
\frac{d N}{d t}=-K N^{2}
$$

Hence: 
$\int_{N_{0}}^{N} \frac{d N}{N^{2}}=-K \int_{0}^{t} d t$

$\frac{1}{N}=K t+1 / N_{0}$

Plot of $\ln (1 / N)$ Vs $t$ produces a slope of $K$ and intercept of $1 / N_{0}$.

For the evaluation of coagulation period $\left(\tau_{1 / 2}\right)$, from Equation 38:

$$
N=\frac{N_{0}}{1+N_{0} K t}
$$

$$
=\frac{N_{0}}{\left[1+\frac{t}{\left(1 / N_{0} K\right)}\right]}
$$

Where $\tau=\left[1 / N_{0} K\right]$

Hence:

$$
N=\frac{N_{0}}{1+(t / \tau)}
$$

When $t=\tau$, equation 41 becomes

$$
N=N_{0} / 2
$$

Therefore as $N_{0} \rightarrow 0.5 N_{0} ; \tau \rightarrow \tau_{1 / 2}$

Hence $\tau_{1 / 2}=1 /\left(0.5 N_{0} K\right)^{\text {for } 2^{\text {nd }} \text { order }}$

And $\tau_{1 / 2}=\frac{\ln 2}{K}$ for $1^{\text {st }}$ order

For Brownian aggregation at early stages ( $t \leq 30$ minutes), equation 14 can be solved exactly, resulting in the expression [15]:

$$
\begin{aligned}
& \frac{N_{m(t)}}{N_{0}}=\frac{\left[t / 2\left(\frac{1}{K N_{0}}\right)\right]^{m-1}}{\left[1+\frac{t}{2\left(\frac{1}{K N_{0}}\right)}\right]^{m+1}} \\
& \text { and } \frac{N_{m(t)}}{N_{0}}=\frac{\left[t / \tau^{\prime}\right]^{m-1}}{\left[1+t / \tau^{\prime}\right]^{m+1}}
\end{aligned}
$$

Equation 46 gives a generic expression for particle of $m$-th order .Hence,

For singlets $(m=1)$

$$
N_{1}=N_{0}\left[\frac{1}{\left(1+t / \tau^{\prime}\right)^{2}}\right]
$$

For doublets $(m=2)$

$$
N_{2}=N_{0}\left[\frac{\left(t / \tau^{\prime}\right)}{\left(1+t / \tau^{\prime}\right)^{3}}\right]
$$


For triplets $(m=3)$

$$
N_{3}=N_{0}\left[\frac{\left(t / \tau^{\prime}\right)^{2}}{\left(1+t / \tau^{\prime}\right)^{4}}\right]
$$

\section{METHODS}

The sample of Mucuna bean seed was sourced from Eke central market, Awka Nigeria and processed to MSC based on the work reported by Adebowale and Adebowale [16].

The jar test was conducted based on standard Bench scale Nephelometric method (single angle procedure) for the examination pf water and waste water [13,17] using model WZS-185 MC Turbidimeter, APPNo 688644A Gulenhamp magnetic stirrer and mettler Toledo Delta $320 \mathrm{pH}$ meter.

\section{RESULTS AND DISCUSSION}

\subsection{Coag-Flocculation Parameters}

The values of coag-flocculation functional parameters are presented in tables 1 to 5 . The general trends indicate that for $\mathrm{pH}$ of 8 and 10 the values of $\alpha=1$ while that of $\mathrm{pH}$ of 2 to 6 , the $\alpha=2$. The significant of this is that the optimum $\mathrm{pH}=6$ and this is recorded for $\alpha=2$. For the case of $\alpha$ $=1$, it is a shift from theoretical expectation but in line with empirical evidence[13].

The optimum $K$ are recorded for $\mathrm{pH}=6$ for all the dosages, though the coag-flocculation performance at $\mathrm{pH}=2$ and 4 are very high. These facts are confirmed by the values of $\tau_{1 / 2}$ recorded between $\mathrm{pH}=2$ and $\mathrm{pH}=6$ with $\mathrm{pH}$ of 6 having the lowest values

Generally, the value of $\alpha$ affects that of $K$ inversely. Since $K$ is rate per concentration and $K$ is associated with energy barrier $(K T)$, it is understandable that for higher $\alpha$ to be obtained, a lower $K$ is a necessary condition for such phenomenon [12]. The values of $K$ are computed from graphs represented by selected sample plots of Figs 1 and $2 . K\left(=0.5 \beta_{B r}\right)$ values are les sensitive to $\mathrm{pH}=2$ to $\mathrm{pH}=6$ for all the dosages studied. Variation in $K_{R}$ is generally minimal as presented in tables 1 to 5 . This is because $K_{R}=f n(T, \eta)$ both of which did not vary considerably during the study. The values of $\alpha$ and $K$ are to a large extent consistent with previous works [11].

At nearly invariant values of $K_{R}, \varepsilon_{p}$ directly relates to $2 K=\beta_{B r}$. The consequence is that high $\varepsilon_{p}$ results in high kinetic energy to overcome the zeta potential $Z p$. The implication is that the double layer is either reduced or the colloids destabilized to actualize low $\tau_{1 / 2}$ in favor of coagulation rate. The results show that high values of $\tau_{1 / 2}$ corresponds to low $\varepsilon \mathrm{p}$ and $K$, an indication of repulsion in the system. $\tau_{1 / 2}$ values lie within the range of previous works where milliseconds had been obtained [7].

Generally, the discrepancies in the parameters $\left(\alpha, K, K_{R}, \varepsilon_{p},(S P)_{0}^{c}\right)$ can be explained by the unattainable assumption that mixing of particles and coagulants throughout the dispersion is $100 \%$ efficient before any aggregation occurs. The effect of these limitations will be local increase in particle ratios during the mixing phase given uneven distribution of particles/coagulant complexes. This complexity makes it impossible to have all $\alpha=2$ [18]. Another account is the effects of interplay between and among the van der walls forces, hydrodynamic interactions, type of counter ion and other short range forces which systematically increase or reduce the values of parameters $[15,19]$. 
Table 1. Coag-flocculation Functional parameters for varying $\mathrm{pH}$ and constant dosage of 0.05 $\mathrm{kg} / \mathrm{m}^{3} \mathrm{MSC}$

\begin{tabular}{|c|c|c|c|c|c|}
\hline Parameter & $\mathrm{pH}=2$ & $\mathrm{pH}=4$ & $\mathrm{pH}=6$ & $\mathrm{pH}=8$ & $\mathrm{pH}=10$ \\
\hline$\alpha$ & 2 & 2 & 2 & 1 & 1 \\
\hline$R^{2}$ & 0.862 & 0.852 & 0.945 & 0.954 & 0.861 \\
\hline$K$ & $\begin{array}{l}3.333 \times 10^{-} \\
{ }^{3} \mathrm{~m}^{3} / \mathrm{kg} . \mathrm{s}\end{array}$ & $\begin{array}{l}3.333 \times 10^{-} \\
{ }^{3} \mathrm{~m}^{3} / \mathrm{kg} . \mathrm{s}\end{array}$ & $\begin{array}{l}6.667 \times 10^{-} \\
{ }^{3} \mathrm{~m}^{3} / \mathrm{kg} . \mathrm{s}\end{array}$ & $7.767 \times 10^{-4} \mathrm{~s}^{-1}$ & $6.817 \times 10^{-4} \mathrm{~s}^{-1}$ \\
\hline$\beta_{B r}$ & $\begin{array}{l}6.666 \times 10^{-} \\
{ }^{3} \mathrm{~m}^{3} / \mathrm{kg} . \mathrm{s}\end{array}$ & $\begin{array}{l}6.666 \times 10^{-} \\
{ }^{3} \mathrm{~m}^{3} / \mathrm{kg} . \mathrm{s}\end{array}$ & $\begin{array}{l}1.333 \times 10^{-} \\
{ }^{2} \mathrm{~m}^{3} / \mathrm{kg} . \mathrm{s}\end{array}$ & $1.553 \times 10^{-3} \mathrm{~s}^{-1}$ & $1.363 \times 10^{-3} \mathrm{~s}^{-1}$ \\
\hline$K_{R}$ & $\begin{array}{l}1.434 \times 10^{-} \\
{ }^{17} \mathrm{~m}^{3} / \mathrm{s}\end{array}$ & $\begin{array}{l}1.407 \times 10^{-} \\
{ }^{17} \mathrm{~m}^{3} / \mathrm{s}\end{array}$ & $\begin{array}{l}1.549 \times 10^{-} \\
{ }^{17} \mathrm{~m}^{3} / \mathrm{s}\end{array}$ & $\begin{array}{l}1.391 \times 10^{-} \\
{ }^{17} \mathrm{~m}^{3} / \mathrm{s}\end{array}$ & $\begin{array}{l}1.361 \times 10^{-} \\
17 \mathrm{~m}^{3} / \mathrm{s}\end{array}$ \\
\hline$\varepsilon_{p}$ & $4.648 \times 10^{14} \mathrm{~kg}^{-1}$ & $4.736 \times 10^{14} \mathrm{~kg}^{-1}$ & $8.607 \times 10^{14} \mathrm{~kg}^{-1}$ & $11.165 \times 10^{13} \mathrm{~m}^{-3}$ & $10.019 \times 10^{13} \mathrm{~m}^{-3}$ \\
\hline$\tau_{1 / 2}(\sec )$ & 4.344 & 4.344 & 2.167 & 892.449 & 1016.820 \\
\hline$(S P)_{0}^{c}$ & $0.588 \mathrm{~kg} / \mathrm{m}^{3}$ & $2.000 \mathrm{~kg} / \mathrm{m}^{3}$ & $0.073 \mathrm{~kg} / \mathrm{m}^{3}$ & $15.027 \mathrm{~kg} / \mathrm{m}^{3}$ & $9.433 \mathrm{~kg} / \mathrm{m}^{3}$ \\
\hline$-r$ & $3.333 \times 10^{-3} c^{2}$ & $3.333 \times 10^{-3} \mathrm{c}^{2}$ & $6.667 \times 10^{-3} c^{2}$ & $7.767 \times 10^{-4} \mathrm{c}$ & $6.817 \times 10^{-4} \mathrm{c}$ \\
\hline
\end{tabular}

Table 2. Coag-flocculation Functional parameters for varying $\mathrm{pH}$ and constant dosage of $0.1 \mathrm{~kg} / \mathrm{m}^{3} \mathrm{MSC}$

\begin{tabular}{|c|c|c|c|c|c|}
\hline Parameter & $\mathrm{pH}=2$ & $\mathrm{pH}=4$ & $\mathrm{pH}=6$ & $\mathrm{pH}=8$ & $\mathrm{pH}=10$ \\
\hline$\alpha$ & 2 & 2 & 2 & 1 & 1 \\
\hline$R^{2}$ & 0.955 & 0.962 & 0.992 & 0.988 & 0.910 \\
\hline$K$ & $\begin{array}{l}5.000 \times 10^{-} \\
{ }^{3} \mathrm{~m}^{3} / \mathrm{kg} . \mathrm{s}\end{array}$ & $\begin{array}{l}3.333 \times 10^{-} \\
{ }^{3} \mathrm{~m}^{3} / \mathrm{kg} . \mathrm{s}\end{array}$ & $\begin{array}{l}6.667 \times 10^{-} \\
{ }^{3} \mathrm{~m}^{3} / \mathrm{kg} . \mathrm{s}\end{array}$ & $7.200 \times 10^{-4} \mathrm{~s}^{-1}$ & $8.300 \times 10^{-4} \mathrm{~s}^{-1}$ \\
\hline$\beta_{B r}$ & $\begin{array}{l}10.000 \times 10^{-} \\
3 \mathrm{~m}^{3} / \mathrm{kg} . \mathrm{s}\end{array}$ & $\begin{array}{l}6.666 \times 10^{-} \\
{ }^{3} \mathrm{~m}^{3} / \mathrm{kg} . \mathrm{s}\end{array}$ & $\begin{array}{l}13.333 \times 10^{-} \\
3 \mathrm{~m}^{3} / \mathrm{kg} . \mathrm{s}\end{array}$ & $1.440 \times 10^{-3} \mathrm{~s}^{-1}$ & $1.660 \times 10^{-3} \mathrm{~s}^{-1}$ \\
\hline$K_{R}$ & $\begin{array}{l}1.769 \times 10^{-} \\
{ }^{17} \mathrm{~m}^{3} / \mathrm{s}\end{array}$ & $1.720 \times 10^{-17} \mathrm{~m}^{3} / \mathrm{s}$ & $1.739 \times 10^{-17} \mathrm{~m}^{3} / \mathrm{s}$ & $1.481 \times 10^{-17} \mathrm{~m}^{3} / \mathrm{s}$ & $1.417 \times 10^{-17} \mathrm{~m}^{3} / \mathrm{s}$ \\
\hline$\varepsilon_{p}$ & ${ }_{1}^{5.653 \times 10^{14} \mathrm{~kg}^{-}}$ & $3.875 \times 10^{14} \mathrm{~kg}^{-1}$ & $7.668 \times 10^{14} \mathrm{~kg}^{-1}$ & $9.722 \times 10^{13} \mathrm{~m}^{-3}$ & $11.712 \times 10^{13} \mathrm{~m}^{-3}$ \\
\hline$\tau_{1 / 2}(\sec )$ & 2.890 & 4.335 & 2.167 & 962.691 & 835.107 \\
\hline$(S P)_{0}^{c}$ & $0.625 \mathrm{~kg} / \mathrm{m}^{3}$ & $1.666 \mathrm{~kg} / \mathrm{m}^{3}$ & $0.833 \mathrm{~kg} / \mathrm{m}^{3}$ & $9.853 \mathrm{~kg} / \mathrm{m}^{3}$ & $6.424 \mathrm{~kg} / \mathrm{m}^{3}$ \\
\hline$-r$ & $5.000 \times 10^{-3} \mathrm{c}^{2}$ & $3.333 c^{2}$ & $6.667 c^{2}$ & $7.200 \times 10^{-4} \mathrm{c}$ & $8.300 \times 10^{-4} \mathrm{c}$ \\
\hline
\end{tabular}

Table 3. Coag-flocculation Functional parameters for varying $\mathrm{pH}$ and constant dosage of $0.15 \mathrm{~kg} / \mathrm{m}^{3} \mathrm{MSC}$

\begin{tabular}{|c|c|c|c|c|c|}
\hline Parameter & $\mathbf{p H}=2$ & $\mathrm{pH}=4$ & $\mathrm{pH}=6$ & $\mathrm{pH}=8$ & $\mathrm{pH}=10$ \\
\hline$\alpha$ & 2 & 2 & 2 & 1 & 1 \\
\hline$R^{2}$ & 0.995 & 0.999 & 0.830 & 0.730 & 0.954 \\
\hline$K$ & $\begin{array}{l}3.333 \times 10^{-} \\
{ }^{3} \mathrm{~m}^{3} / \mathrm{kg} . \mathrm{s}\end{array}$ & $\begin{array}{l}6.667 \times 10^{-} \\
{ }^{3} \mathrm{~m}^{3} / \mathrm{kg} . \mathrm{s}\end{array}$ & $\begin{array}{l}8.333 \times 10^{-} \\
{ }^{3} \mathrm{~m}^{3} / \mathrm{kg} . \mathrm{s}\end{array}$ & $2.205 \times 10^{-4} \mathrm{~s}^{-1}$ & $7.150 \times 10^{-4} \mathrm{~s}^{-1}$ \\
\hline$\beta_{B r}$ & $\begin{array}{l}6.667 \times 10^{-} \\
{ }^{3} \mathrm{~m}^{3} / \mathrm{kg} . \mathrm{s}\end{array}$ & $\begin{array}{l}13.333 \times 10^{-} \\
{ }^{3} \mathrm{~m}^{3} / \mathrm{kg} . \mathrm{s}\end{array}$ & $\begin{array}{l}16.667 \times 10^{-} \\
{ }^{3} \mathrm{~m}^{3} / \mathrm{kg} . \mathrm{s}\end{array}$ & $4.410 \times 10^{-3} \mathrm{~s}^{-1}$ & $1.430 \times 10^{-3} \mathrm{~s}^{-1}$ \\
\hline$K_{R}$ & $\begin{array}{l}1.418 \times 10^{-} \\
{ }^{17} \mathrm{~m}^{3} / \mathrm{s}\end{array}$ & $1.384 \times 10^{-17} \mathrm{~m}^{3} / \mathrm{s}$ & $\begin{array}{l}1.379 \times 10^{-} \\
{ }^{17} \mathrm{~m}^{3} / \mathrm{s}\end{array}$ & $\begin{array}{l}1.284 \times 10^{-} \\
{ }^{17} \mathrm{~m}^{3} / \mathrm{s}\end{array}$ & $\begin{array}{l}1.131 \times 10^{-} \\
{ }^{17} \mathrm{~m}^{3} / \mathrm{s}\end{array}$ \\
\hline$\varepsilon_{p}$ & $4.702 \times 10^{14} \mathrm{~kg}^{-1}$ & $9.631 \times 10^{14} \mathrm{~kg}^{-1}$ & ${ }_{1}^{12.087 \times 10^{14} \mathrm{~kg}^{-}}$ & $3.435 \times 10^{14} \mathrm{~m}^{-3}$ & $2.528 \times 10^{14} \mathrm{~m}^{-3}$ \\
\hline$\tau_{1 / 2}(\mathrm{sec})$ & 4.344 & 2.167 & 1.734 & 314.352 & 969.423 \\
\hline$(S P)_{0}^{c}$ & $0.500 \mathrm{~kg} / \mathrm{m}^{3}$ & $3.333 \mathrm{~kg} / \mathrm{m}^{3}$ & $0.0943 \mathrm{~kg} / \mathrm{m}^{3}$ & $36.753 \mathrm{~kg} / \mathrm{m}^{3}$ & $13.220 \mathrm{~kg} / \mathrm{m}^{3}$ \\
\hline$-r$ & $3.333 \times 10^{-3} \mathrm{c}^{2}$ & $6.667 \times 10^{-3} c^{2}$ & $8.333 \times 10^{-3} \mathrm{c}^{2}$ & $2.205 \times 10^{-3} \mathrm{c}$ & $8.300 \times 10^{-4} \mathrm{c}$ \\
\hline
\end{tabular}


Table 4. Coag-flocculation Functional parameters for varying $\mathrm{pH}$ and constant dosage of $0.20 \mathrm{~kg} / \mathrm{m}^{3} \mathrm{MSC}$

\begin{tabular}{|c|c|c|c|c|c|}
\hline Parameter & $\mathrm{pH}=2$ & $\mathrm{pH}=4$ & $\mathrm{pH}=6$ & $\mathrm{pH}=8$ & $\mathrm{pH}=10$ \\
\hline$\alpha$ & 2 & 2 & 2 & 1 & 1 \\
\hline$R^{2}$ & 0.919 & 0.8537 & 0.814 & 0.975 & 0.986 \\
\hline$K$ & $\begin{array}{l}8.333 \times 10^{-} \\
{ }^{3} \mathrm{~m}^{3} / \mathrm{kg} . \mathrm{s}\end{array}$ & $\begin{array}{l}5.000 \times 10^{-} \\
{ }^{3} \mathrm{~m}^{3} / \mathrm{kg} . \mathrm{s}\end{array}$ & $\begin{array}{l}8.333 \times 10^{-} \\
{ }^{3} \mathrm{~m}^{3} / \mathrm{kg} . \mathrm{s}\end{array}$ & $6.300 \times 10^{-4} \mathrm{~s}^{-1}$ & $7.550 \times 10^{-4} \mathrm{~s}^{-1}$ \\
\hline$\beta_{B r}$ & $\begin{array}{l}16.667 \times 10^{-} \\
{ }^{3} \mathrm{~m}^{3} / \mathrm{kg} . \mathrm{s}\end{array}$ & $\begin{array}{l}10.000 \times 10^{-} \\
{ }^{3} \mathrm{~m}^{3} / \mathrm{kg} . \mathrm{s}\end{array}$ & $\begin{array}{l}16.667 \times 10^{-} \\
{ }^{3} \mathrm{~m}^{3} / \mathrm{kg} . \mathrm{s}\end{array}$ & $1.260 \times 10^{-3} \mathrm{~s}^{-1}$ & $1.510 \times 10^{-3} \mathrm{~s}^{-1}$ \\
\hline$K_{R}$ & $\begin{array}{l}1.418 \times 10^{-} \\
{ }^{17} \mathrm{~m}^{3} / \mathrm{s}\end{array}$ & $1.384 \times 10^{-17} \mathrm{~m}^{3} / \mathrm{s}$ & $\begin{array}{l}1.379 \times 10^{-} \\
{ }^{17} \mathrm{~m}^{3} / \mathrm{s}\end{array}$ & $\begin{array}{l}1.284 \times 10^{-} \\
{ }^{17} \mathrm{~m}^{3} / \mathrm{s}\end{array}$ & $\begin{array}{l}1.425 \times 10^{-} \\
{ }^{17} \mathrm{~m}^{3} / \mathrm{s}\end{array}$ \\
\hline$\varepsilon_{p}$ & ${ }_{-1}^{11.757 \times} \times 10^{14} \mathrm{~kg}$ & $7.223 \times 10^{14} \mathrm{~kg}^{-1}$ & ${ }_{1}^{12.087 \times 10^{14} \mathrm{~kg}^{-}}$ & $9.816 \times 10^{13} \mathrm{~m}^{-3}$ & $10.592 \times 10^{13} \mathrm{~m}^{-3}$ \\
\hline$\tau_{1 / 2}(\sec )$ & 1.734 & 2.890 & 1.734 & 1100.216 & 918.076 \\
\hline$(S P)_{0}^{c}$ & $0.333 \mathrm{~kg} / \mathrm{m}^{3}$ & $0.909 \mathrm{~kg} / \mathrm{m}^{3}$ & $0.1052 \mathrm{~kg} / \mathrm{m}^{3}$ & $4.991 \mathrm{~kg} / \mathrm{m}^{3}$ & $14.869 \mathrm{~kg} / \mathrm{m}^{3}$ \\
\hline$-r$ & $8.333 \times 10^{-3} \mathrm{c}^{2}$ & $5.000 \times 10^{-3} \mathrm{c}^{2}$ & $8.333 \times 10^{-3} c^{2}$ & $6.300 \times 10^{-4} \mathrm{c}$ & $7.550 \times 10^{-4} \mathrm{c}$ \\
\hline
\end{tabular}

Table 5. Coag-flocculation Functional parameters for varying $\mathrm{pH}$ and constant dosage of $0.25 \mathrm{~kg} / \mathrm{m}^{3} \mathrm{MSC}$

\begin{tabular}{|c|c|c|c|c|c|}
\hline Parameter & $\mathrm{pH}=2$ & $\mathrm{pH}=4$ & $\mathrm{pH}=6$ & $\mathrm{pH}=8$ & $\mathrm{pH}=10$ \\
\hline$\alpha$ & 2 & 2 & 2 & 1 & 1 \\
\hline$R^{2}$ & 0.905 & 0.912 & 0.956 & 0.999 & 0.966 \\
\hline$K$ & $\begin{array}{l}6.667 \times 10^{-} \\
{ }^{3} \mathrm{~m}^{3} / \mathrm{kg} . \mathrm{s}\end{array}$ & $\begin{array}{l}5.000 \times 10^{-} \\
{ }^{3} \mathrm{~m}^{3} / \mathrm{kg} . \mathrm{s}\end{array}$ & $\begin{array}{l}8.333 \times 10^{-} \\
{ }^{3} \mathrm{~m}^{3} / \mathrm{kg} . \mathrm{s}\end{array}$ & $1.082 \times 10^{-3} \mathrm{~s}^{-1}$ & $9.334 \times 10^{-4} \mathrm{~s}^{-1}$ \\
\hline$\beta_{B r}$ & $\begin{array}{l}13.333 \times 10^{-} \\
{ }^{3} \mathrm{~m}^{3} / \mathrm{kg} . \mathrm{s}\end{array}$ & $\begin{array}{l}10.000 \times 10^{-} \\
{ }^{3} \mathrm{~m}^{3} / \mathrm{kg} . \mathrm{s}\end{array}$ & $\begin{array}{l}16.667 \times 10^{-} \\
{ }^{3} \mathrm{~m}^{3} / \mathrm{kg} . \mathrm{s}\end{array}$ & $2.163 \times 10^{-3} \mathrm{~s}^{-1}$ & $1.8670 \times 10^{-3} \mathrm{~s}^{-1}$ \\
\hline$K_{R}$ & $\begin{array}{l}1.584 \times 10^{-} \\
{ }^{17} \mathrm{~m}^{3} / \mathrm{s}\end{array}$ & $1.573 \times 10^{-17} \mathrm{~m}^{3} / \mathrm{s}$ & $\begin{array}{l}1.529 \times 10^{-} \\
{ }^{17} \mathrm{~m}^{3} / \mathrm{s}\end{array}$ & $\begin{array}{l}1.292 \times 10^{-} \\
{ }^{17} \mathrm{~m}^{3} / \mathrm{s}\end{array}$ & $\begin{array}{l}1.143 \times 10^{-} \\
{ }^{17} \mathrm{~m}^{3} / \mathrm{s}\end{array}$ \\
\hline$\varepsilon_{p}$ & $8.417 \times 10^{14} \mathrm{~kg}^{-1}$ & $6.354 \times 10^{14} \mathrm{~kg}^{-1}$ & ${ }_{1}^{10.902 \times 10^{14} \mathrm{~kg}^{-}}$ & $16.740 \times 10^{13} \mathrm{~m}^{-3}$ & $16.335 \times 10^{13} \mathrm{~m}^{-3}$ \\
\hline$\tau_{1 / 2}(\sec )$ & 2.167 & 2.890 & 1.734 & 640.854 & 742.644 \\
\hline$(S P)_{0}^{c}$ & $0.189 \mathrm{~kg} / \mathrm{m}^{3}$ & $1.250 \mathrm{~kg} / \mathrm{m}^{3}$ & $0.270 \mathrm{~kg} / \mathrm{m}^{3}$ & $3.118 \mathrm{~kg} / \mathrm{m}^{3}$ & $17.520 \mathrm{~kg} / \mathrm{m}^{3}$ \\
\hline$-r$ & $6.667 \times 10^{-3} c^{2}$ & $5.000 \times 10^{-3} c^{2}$ & $8.333 \times 10^{-3} c^{2}$ & $1.082 \times 10^{-3} \mathrm{c}$ & $9.334 \times 10^{-4} \mathrm{c}$ \\
\hline
\end{tabular}

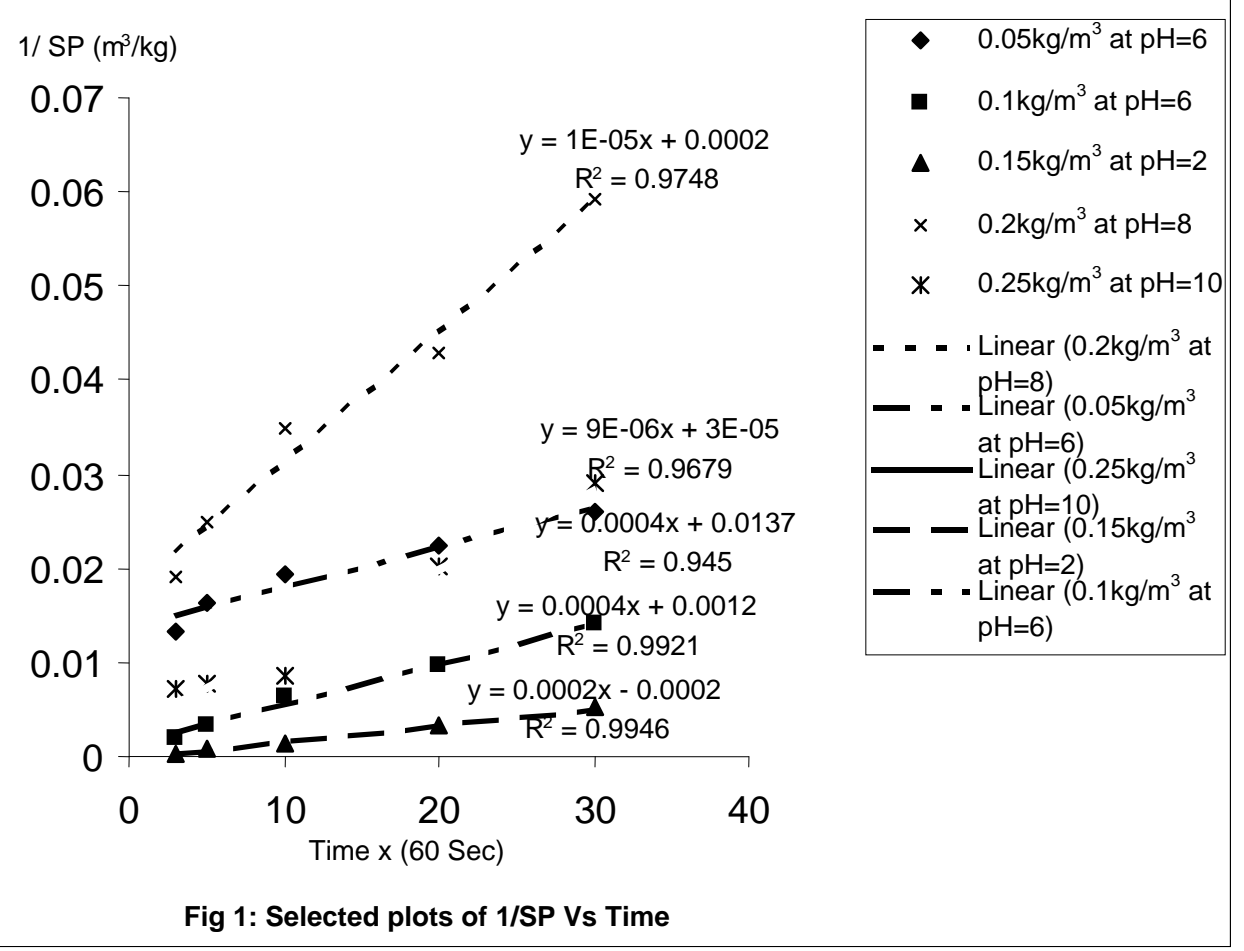




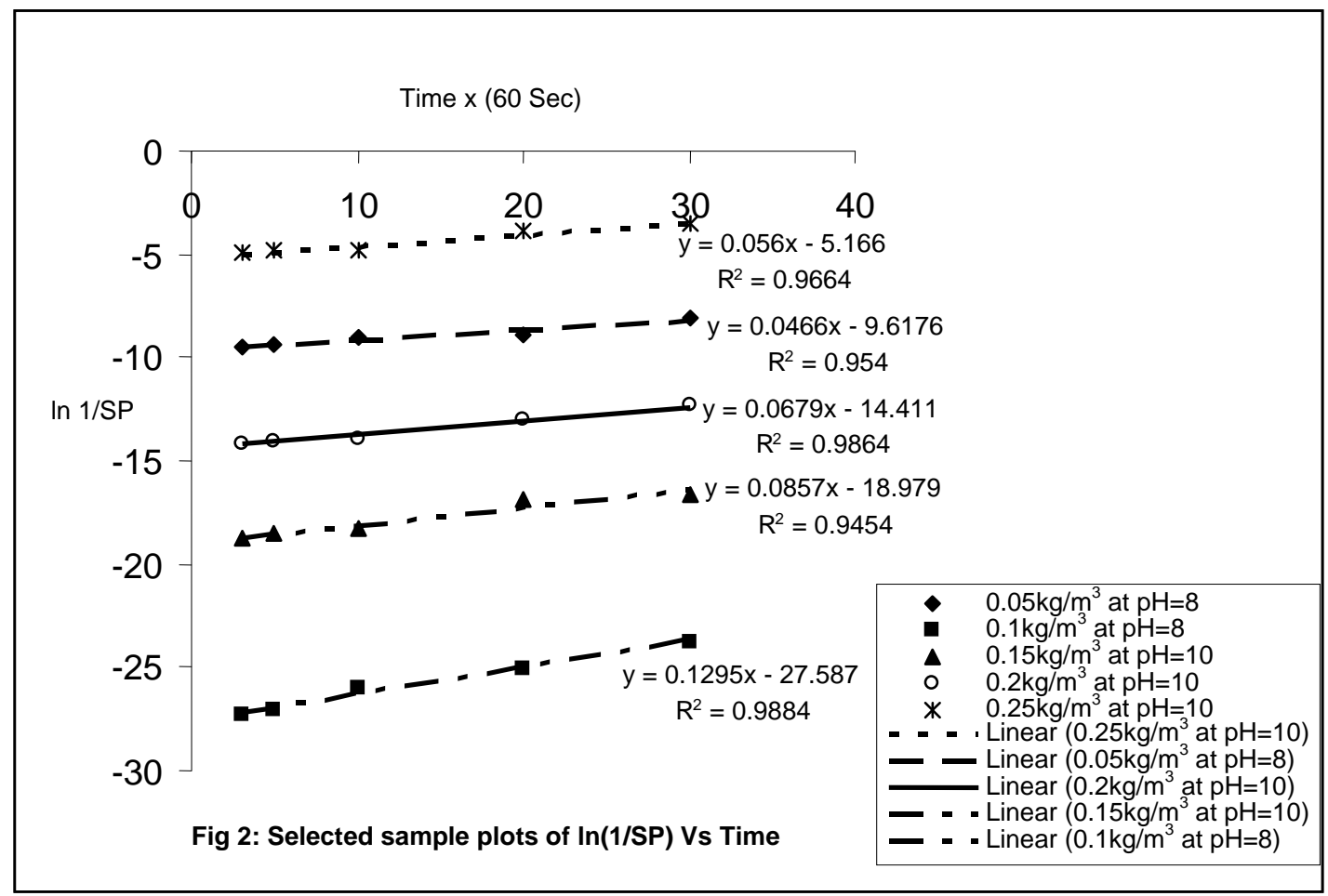

\subsection{SP $\left(=\mathrm{N}_{\mathrm{t}}\right)\left(\mathrm{kg} / \mathrm{m}^{3}\right)$ vs Time Plots}

These are presented in Figures 3-7 with initial $S P$ concentration of $138.415 \mathrm{~kg} / \mathrm{m}^{3}$. The significant feature is that for $\mathrm{pH}$ of 8 and 10, the coagulant performance is poor. Also, starting from $t=10 \mathrm{mins}$, there is extremely minimal variation in the coag-flocculation performance. These significant features are reflected by the values of $K$ for the various $\mathrm{pH}$ as shown in Tables 1 to 5 . One important feature is that, the concentration of SP(hence, turbidity) reduces with time. This behavior simply reflects the complex dependence of turbidity on particle number (dropping) and particle size (increasing) over time [18].

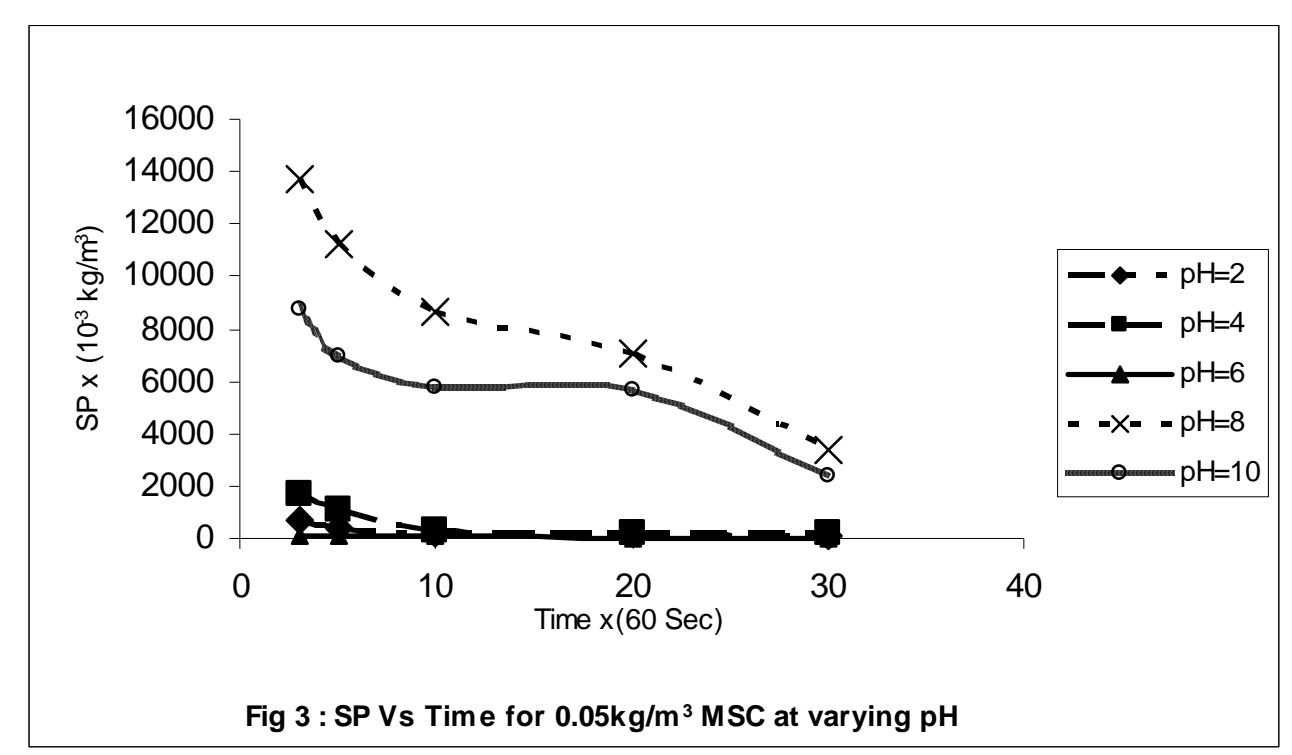



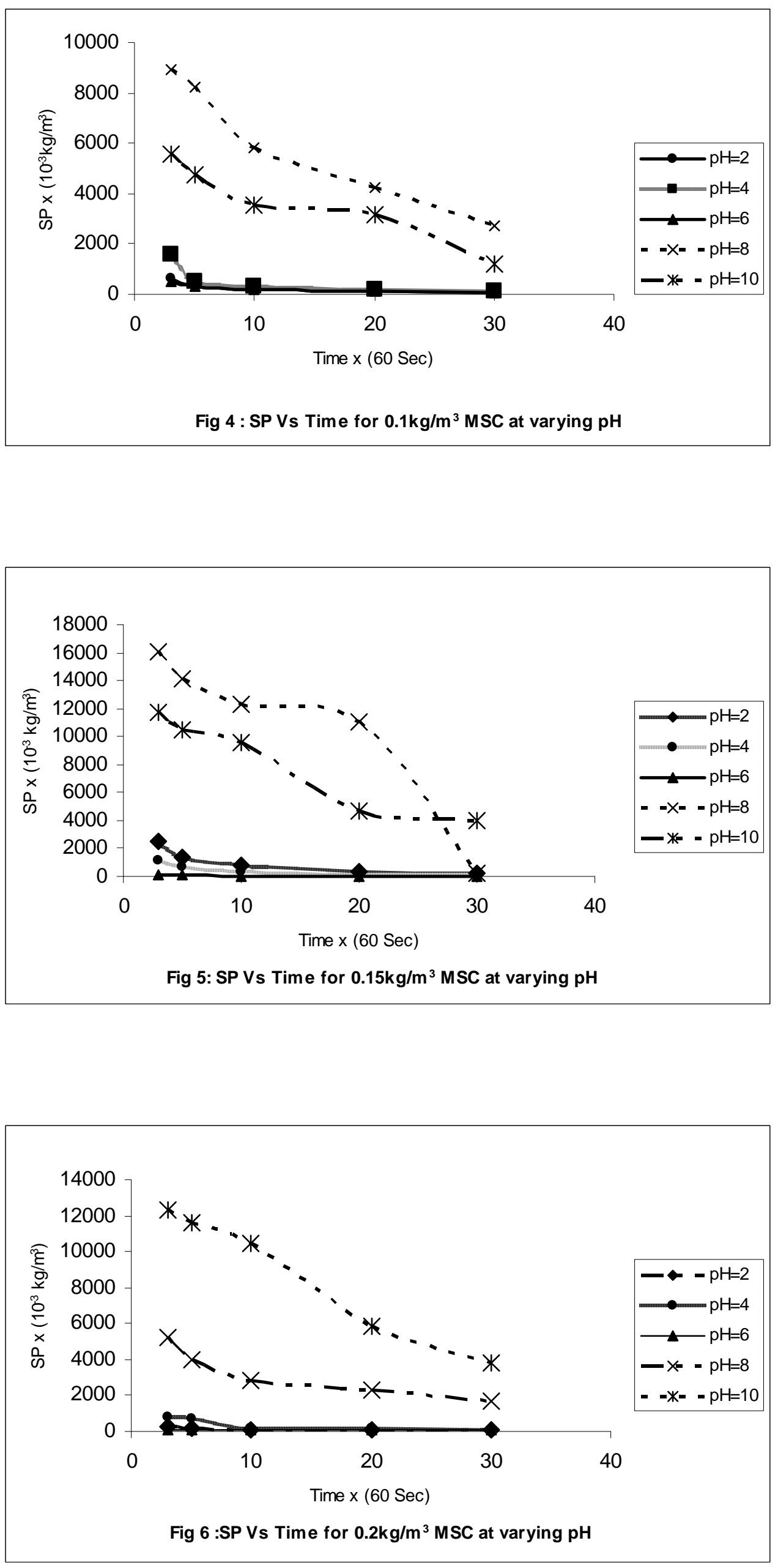


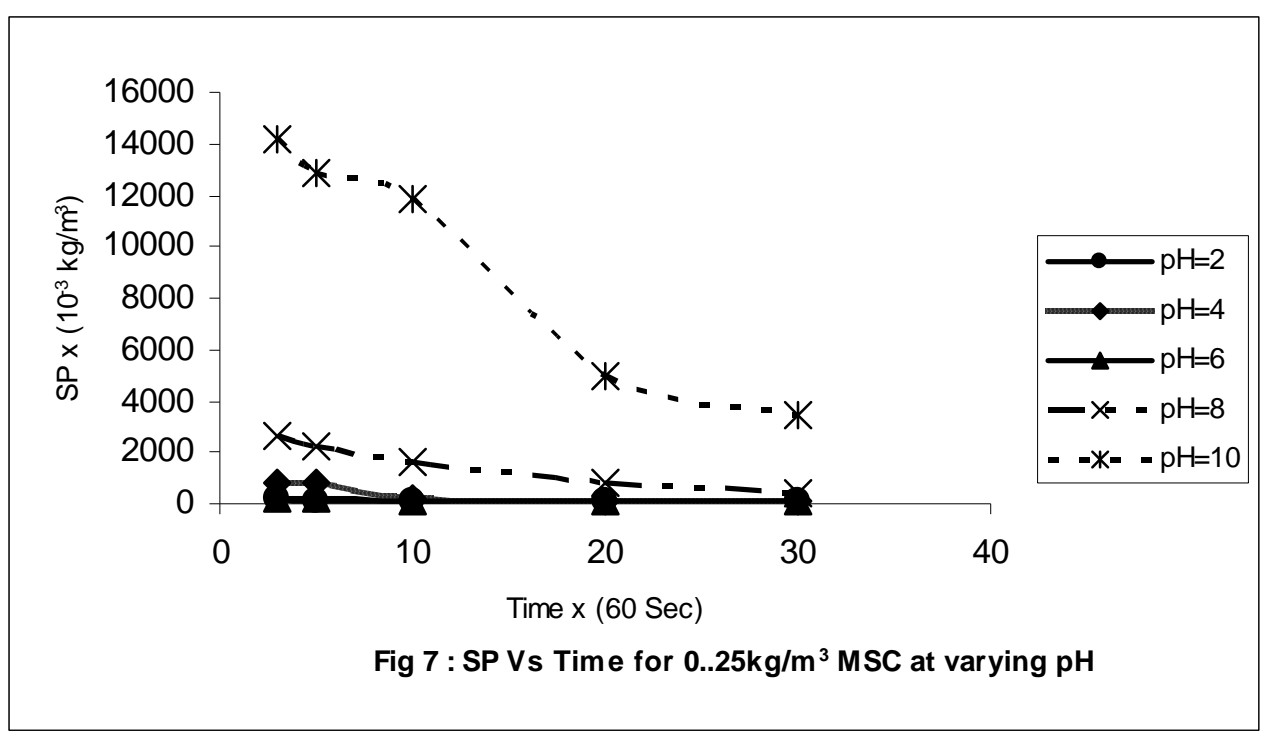

\subsection{Efficiency E (\%) Vs Time Plots}

These are presented in Figures 8 to 12.The significant feature of the figures confirm that the best performance are recorded for $\mathrm{pH}=2$ to $\mathrm{pH}=6$. Also, the underperformance of $\mathrm{pH}$ of 8 and 10 are illustrated. Note that starting from $t=10 \mathrm{~min}$, there is virtually no variation in $\mathrm{E}(\%)$ values for $\mathrm{pH}$ of 2 to 6 . With the least $\mathrm{E}>90 \%$, it confirms the effectiveness of MSC to remove turbidity from the effluent. At $\mathrm{E}(\%)>90 \%$, it justifies the theory of fast coagulation which validates the real life application of coag-flocculation.
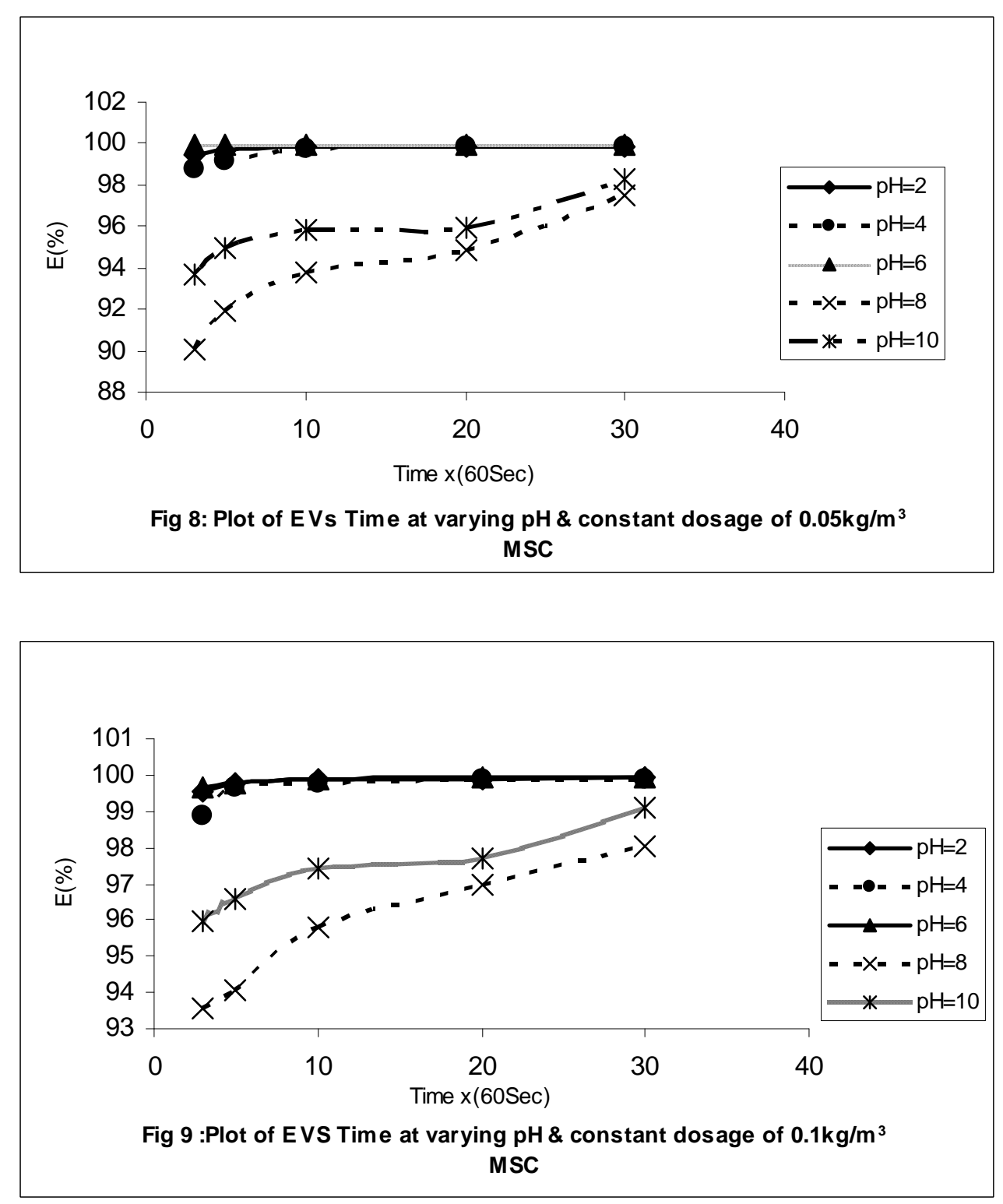

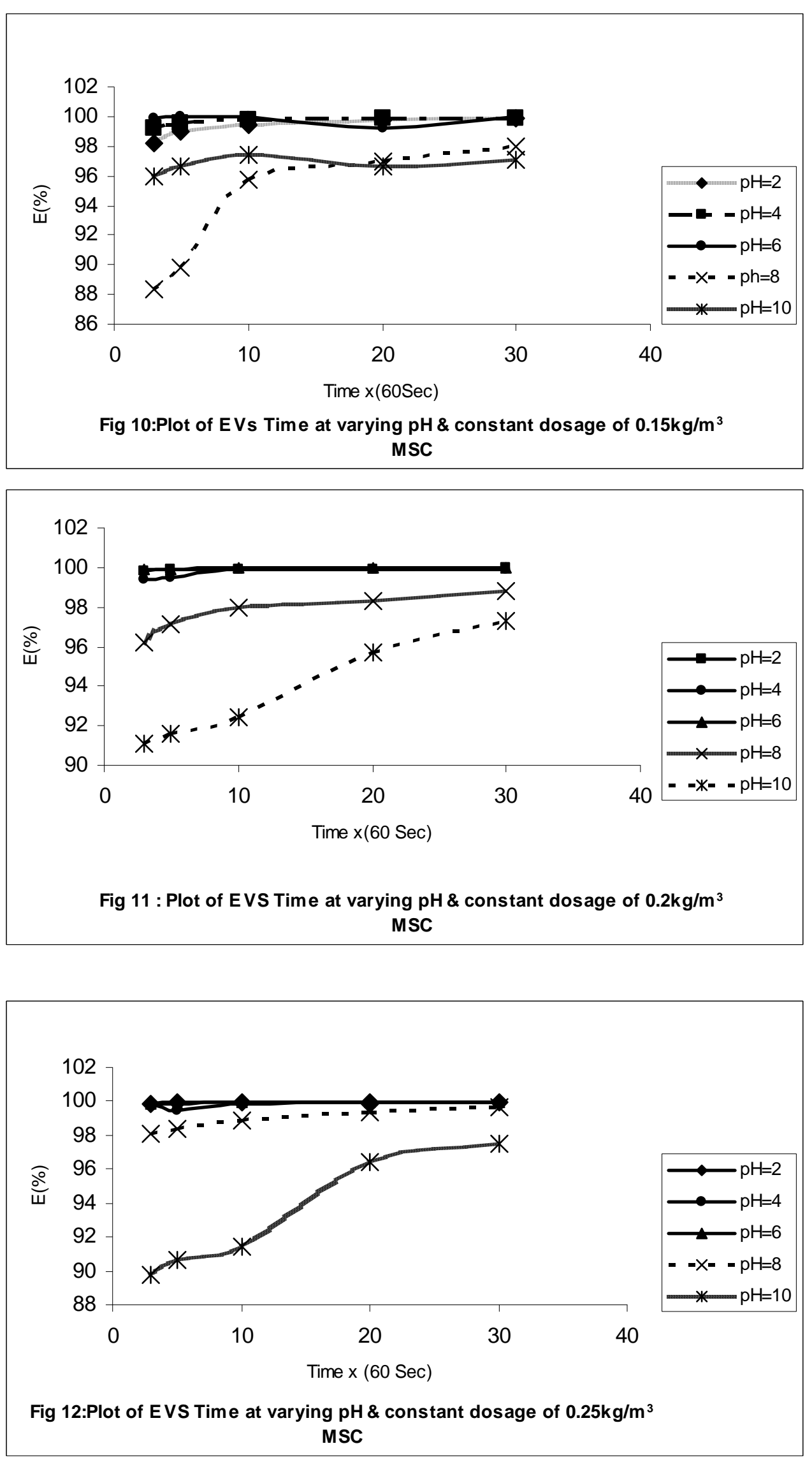

\subsection{Plots of E (\%) vs pH}

This is represented in Figure 13. It indicates the performance of various doses of MSC at varying $\mathrm{pH}$. The significant feature indicates that between $\mathrm{pH}$ of 2 and 6, near constant $\mathrm{E}(\%)$ value is recorded followed by downward movement of $\mathrm{E}$. At $\mathrm{pH}=6$, optimum $\mathrm{E}$ is recorded. Thus, it can be deduced that between $\mathrm{pH}$ of 2 and 6 , the dosage has negligible effect on $\mathrm{E}$. 


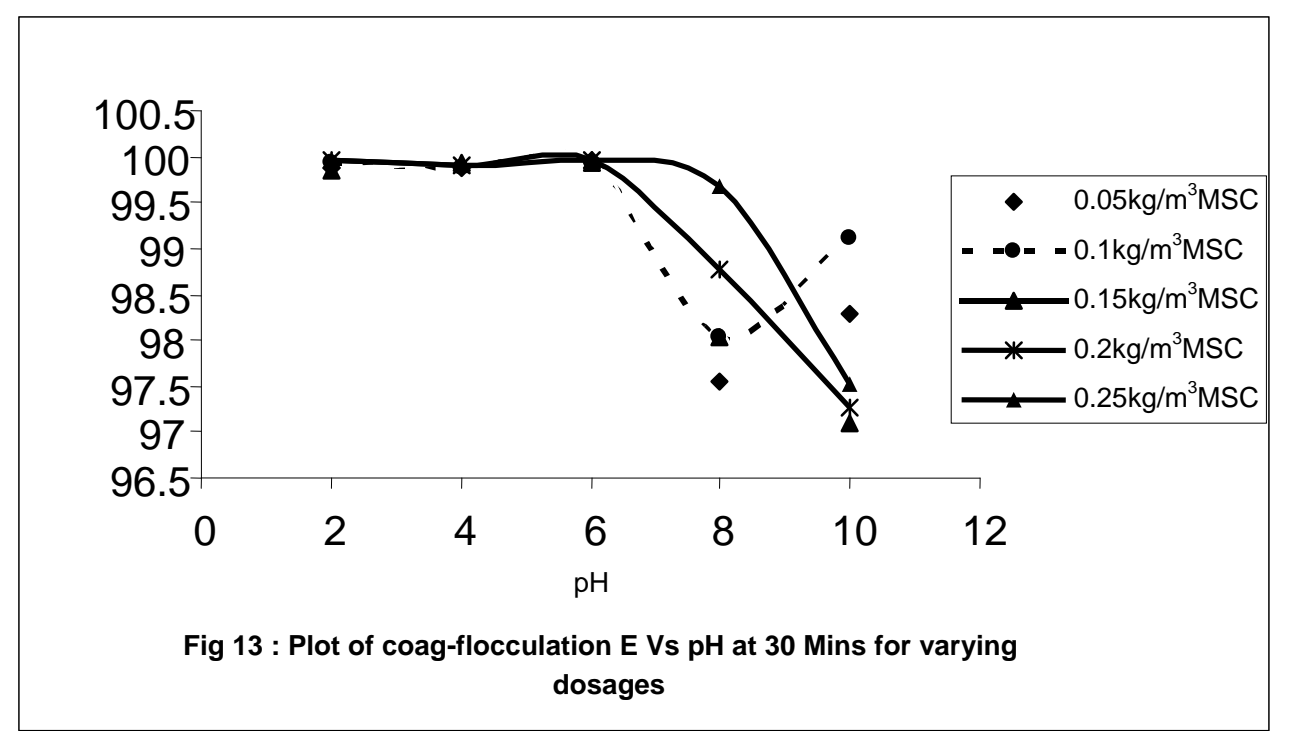

\subsection{Plots of E (\%) Vs Dosage $\left(\mathrm{kg} / \mathrm{m}^{3}\right)$}

This is presented in Figure 14. It confirms the observations made from Figs. 3 to 13 . The significant feature shows that there is very negligible variation in the values of $\mathrm{E}(\%)$ at $\mathrm{pH}$ of 2,4 and 6 for all dosages. Also, the difference in the level of performance of $\mathrm{pH}$ of 8 and 10 are illustrated. The optimum performance is recorded at $\mathrm{pH}=6$ for all dosages.

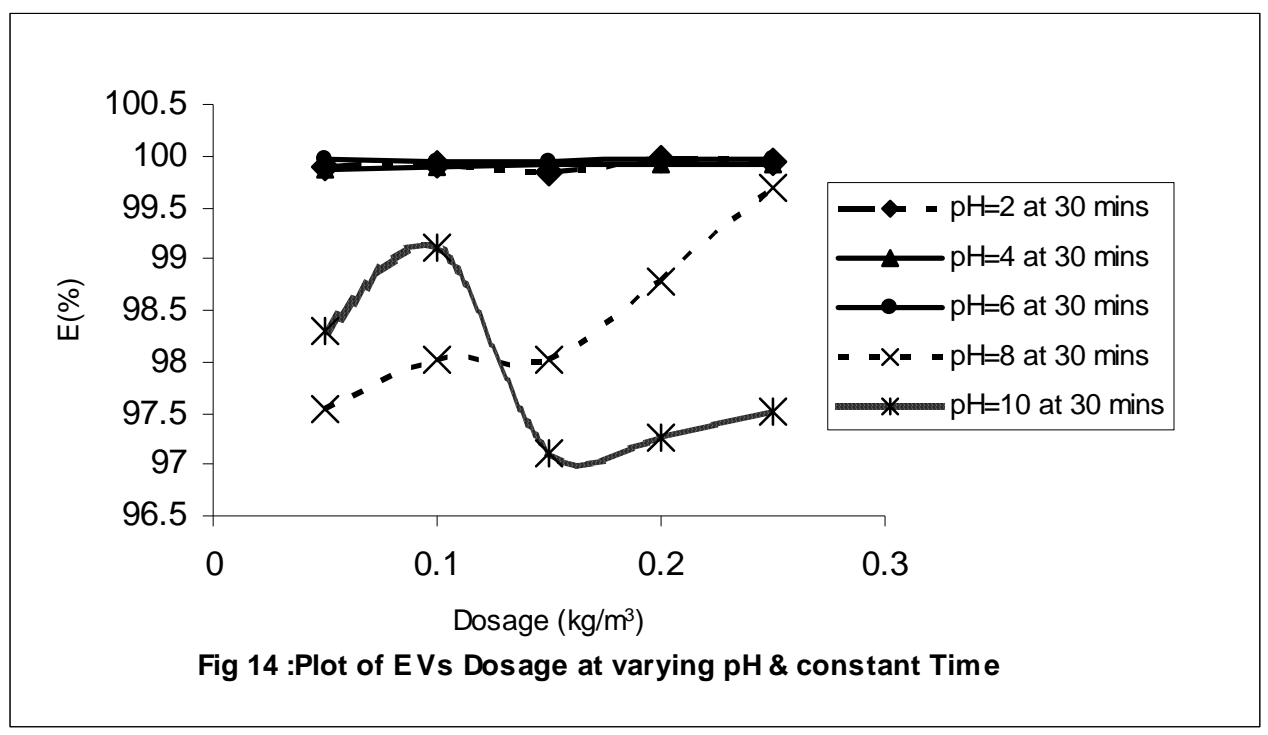

\subsection{Particle Distribution Plots}

These are presented in Figs 15 and 16 for $\tau=2.1673 \mathrm{sec}$ and $\tau=1.7339 \mathrm{sec}$ respectively. The trend is similar for all the curves. These are particle distribution expected in a typical coagflocculation process. For the curves SP $(N)$ Vs t, beginning with doublets, it passes through a maximum because they are absent at initial instant $\left(t=0, N_{2}=0\right)$ and at the end of coagflocculation process $\left(t=\infty, N_{2}=0\right)$. The number of singlets can be seen to decrease more rapidly than the total number of particles. For all consolidated particles, the curves pass through maxima whose height lowers with increase consolidation.

The curves are expected in coag-flocculation where there is absence of excessive colloidal entrapment and high sheer resistance .Mainly, the dominant mechanism in these graphs are charge neutralization combined with low bridging to ensure moderate speed of coag-flocculation as represented in figs 15 and 16. The discrete nature of formation of singlet, doublet and triplet is associated with moderate energy barrier. 

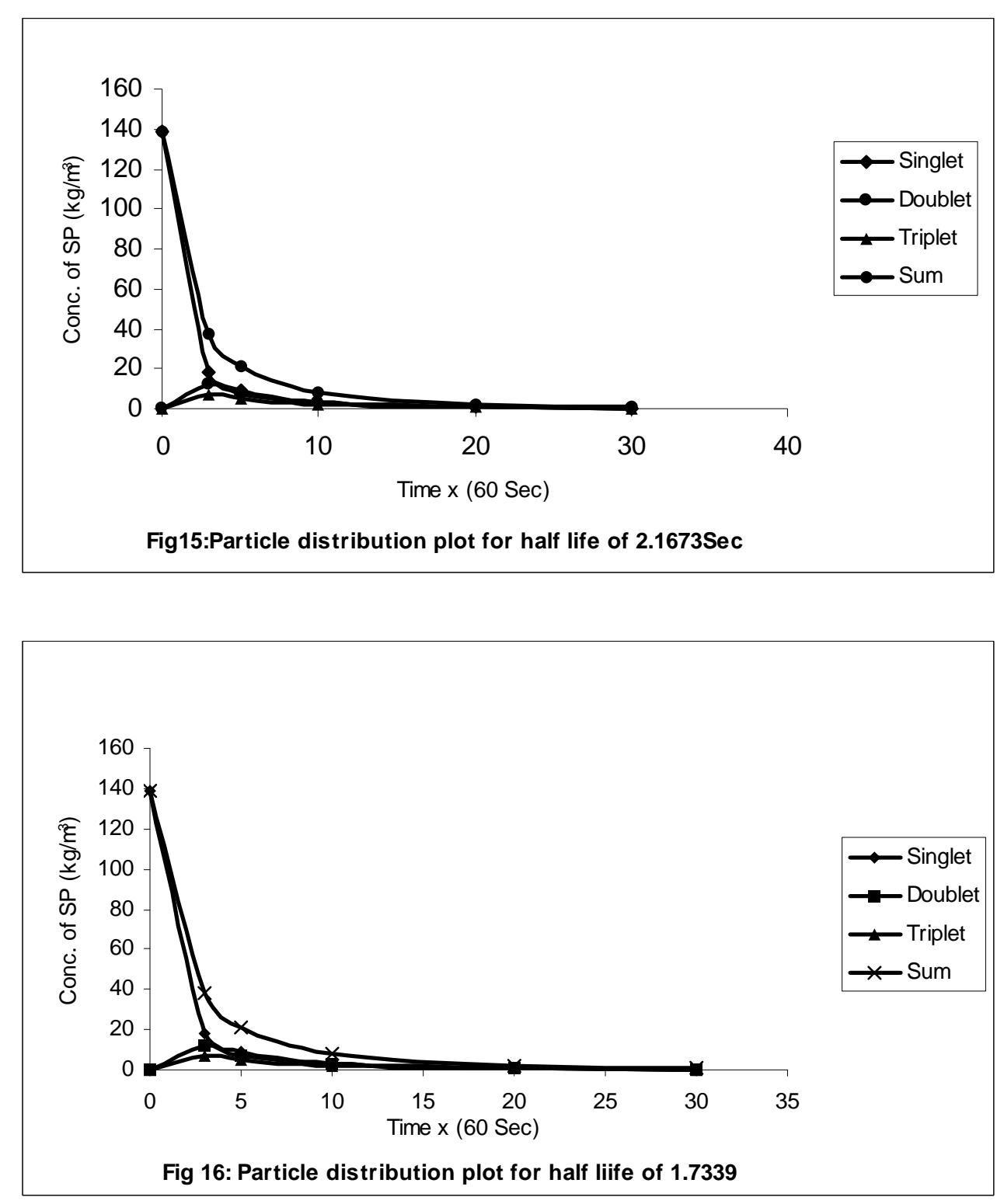

\section{CONCLUSION}

The high value of SP reduction recorded within the first 3 minutes supported with $E \geq 80 \%$ presents the potential of MSC as a bio-coagulant applicable in large scale water treatment. The computed experimental results highly agree with previous similar works $[5,11$, $15]$.

\section{NOMENCLATURE:}

$K: \alpha^{\text {th }}$ order coag-flocculation constant

$\beta_{B R}$ :Collision factor for Brownian Transport

$\varepsilon_{p}$ :Collision Efficiency

$\tau_{1 / 2}:$ Coagulation Period / Half life

$E$ : Coag-floculation Efficiency

$R^{2}$ : Coefficient of Determination

$\alpha$ : Coag-flocculation reaction order

$-r$ : Coag-flocculation reaction rate

$(S P)_{0}^{c}$ : Computed initial suspended particle $\left(\mathrm{kg} / \mathrm{m}^{3}\right)$

$J_{f}:$ Flux

$f_{d}$ : Drag force 


\section{REFERENCES}

[1] Ma,J.J.,Li, G.,Chen,G.R.,Xu,G.O., and Cai, G.Q., 2001, "Enhanced coagulation of surface waters with high organic content by permanganate perooxidation." Water science and Technology: Water Supply, Vol 1,pp. 51-61

[2] Diterlizzi, S.D., 1994, Introduction to Coagulation and Flocculation of Waste water, Environmental System Project, U.S.A ,pp 1-4.

[3] Edzwald,J.K.,1987, “Coagulation - sedimentation filtration process for removing organic substances in drinking and waste water.",Noyes Data Corporation ,Park Bridge ,New Jersey, pp 2627.

[4] O'Meila C.R., 1978, Coagulation in waste water treatment : The scientific basis of flocculation (NATO Advanced study Inst. Series E,Appl.Sc.No 27), In : Sijtholf and Noordhoff,Alpenan den Rijn, pp 219-268, (Ives ,K.J., Ed.),Netherlands.

[5] Jin, Y.,2005, Use of high Resolution Photographic Technique for studying

Coagulation/flocculation in water treatment, M.Sc thesis, University of Saskatchewan, Saskatoon, Canada.

[6] Guerranti ,R.,Aguiyi, J.C., Neri, S., Leoncini ,R., Pagani, R., and Marinello, E.,2002, "Proteins from Mucuna pruriens and Enzymes from Echis carrinatus Venom." Published,JBC papers in press,DOI 10.1074/jbc.M201387200

[7] Hunter, R.J., 1993; Introduction to Modern Colloid Science, Oxford University Press, New York, pp 33-38;289-290

[8] Thomas,D.N., Judd,S.J., and Fawcett,N.,1999;““ Flocculation modeling: A review”. Water Resources, Vol 33, pp. 1579-1592.

[9] Swift, D.L., and Friedlander, S.K., 1964 "The coagulation of hydrolysis by Brownian motion and laminar shear flow." Journal of Colloid Science, Vol 19, pp. 621.

[10] Von Smoluchowski,M., 1917; "Versucheiner Mathematischen Theorie der Koagulations Kinetic Kolloider Lousungen.” Z. Phys. Chem. 92: pp. 129-168.

[11] Van Zanten, J.H., and Elimelech M., 1992; "Determination of Rate constants by multi angle light scattering." Journal of colloid and interface Vol 154, pp 621

[12] Fridkhsberg, D.A., 1984; A course in Colloid Chemistry; Mir Publishers Moscow, Russia. pp 266-268

[13] Water Specialist Technology (WST) 2003; About Coagulation and Flocculation: Information Bulletins, U.S.A. pp:1-10

[14] Menkiti, M.C., 2007; Studies on coagulation and flocculation of Coal Washery Effluent: Turbidimetric approach .M.Sc thesis, Nnamdi Azikiwe University Awka, Nigeria. pp.: 51. [15] Holthof, H., Egelhaaf, S.U., Borkovec, M., Schurtenberger, P., and Sticher, H., 1996; "Coagulation Rate Measurement of Colloidal Particles by Simultaneous Static and Dynamic Light Scattering."Langmuir Vol 12, pp. 5541.

[16] Adebowale, Y.A., and Adebowale, K.A., 2007; "Evaluation of the Gelation characteristics of Mucuna Bean Flour and Protein isolate." Electronic Journal of Environmental, Agricultural and Food Chemistry, Vol 6,2007, pp 2243-2262.

[17] AWWA 2005; American Water Works Association;Standard Methods for the Examination of Water and Waste water Effluent, New York, U.S.A.

[18] Yates,P., Yan,Y., Jamson, G. J., and Biggs,S., 2001; "Heteroaggregation of particle system: Aggregation Mechanisms and aggregate structure determination." ${ }^{\text {th }}$ World Congress of Chemical Engineering,Melbourne,Australia,23-27 September,2001. pp: 1-10

[19] Holthof, H., Schmitt, A., Ferńandez-Barbero,M., Borkovec, M., Cabrerizo-Vilehez, P., Schurtenberger, P., and Hidalgo-Alvarez, R.,1997; "Measurement of Absolute Coagulation Rate Constants for Colloidal Particles: Comparison of Single and Multiparticle Light Scattering Techniques." Journal of Colloid and Interface Science, Vol 192, pp. 463-470. 